\title{
Use of Intermittent Bolus Erector Spinae Plane (ESP) Block for Analgesia in Open Cholecystectomy: A Case Report
}

(1) Peter Merjavy

Southern Health and Social Care Trust, Craigavon, Northern Ireland, United Kingdom

\begin{tabular}{|c|}
\hline $\begin{array}{r}\text { Submitted: } 06.03 .2019 \\
\text { Accepted: 04.04.2019 }\end{array}$ \\
\hline $\begin{array}{r}\text { Correspondence: Peter Merjavy, } \\
68 \text { Lurgan Road Craigavon, } \\
\text { United Kingdom }\end{array}$ \\
\hline E-mail:merjavy@yahoo.com \\
\hline 물물 \\
\hline $\begin{array}{r}\text { Keywords: Catheter; } \\
\text { erector spinae plane block; } \\
\text { intermittent boluses; } \\
\text { laparotomy; open } \\
\text { cholecystectomy. }\end{array}$ \\
\hline 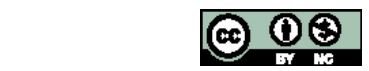 \\
\hline $\begin{array}{l}\text { This work is licensed under a Creative Commons } \\
\text { Attribution-NonCommercial } 4.0 \text { International License. }\end{array}$ \\
\hline
\end{tabular}

\begin{abstract}
The ultrasound-guided erector spinae plane (ESP) block has been recently described for postoperative analgesia after various thoracic and abdominal surgeries, mostly laparoscopic. Some authors suggest that the ESP block has an effect on both visceral and somatic pain. We describe the successful use of continuous ESP block using intermittent boluses via catheter in open cholecystectomy (OC). Our patient was scheduled for laparoscopic cholecystectomy, which unexpectedly led to open procedure. Continuous ESP block provided good analgesia for $96 \mathrm{~h}$ after surgery. To our knowledge, this is the first case report of the use of continuous ESP block using intermittent boluses for OC.
\end{abstract}

\section{INTRODUCTION}

Ultrasound-guided erector spinae plane (ESP) block has been first described by Forero as an analgesia technique for thoracic neuropathic pain. ${ }^{[l]}$ It offers good postoperative analgesia for thoracic/breast surgery with injection at the T5 level. ${ }^{[2]}$ Some authors suggested that ESP block has an analgesic effect not only on somatic but also on visceral pain. Local anesthesia probably spreads toward the paravertebral space affecting the ventral rami and rami communicantes that include sympathetic nerve fibers. ${ }^{[1,3]}$ Bilateral ESP blocks at the lower level (T8) have been found to be effective as thoracic epidural analgesia for major abdominal surgery in some case reports. ${ }^{[3,4]}$ Multiple other case reports used T7 as an optimal point of injection for various, mostly laparoscopic, abdominal procedures. $^{[2-5]}$

We are not aware of any previous report of the successful use of continuous ESP block using intermittent boluses for postoperative analgesia after open cholecystectomy (OC).

\section{CASE REPORT}

Patient's consent was obtained for this case report. REC approval for case report was not required by our institution.

A 67-year-old male patient (weight: $101 \mathrm{~kg}$, height: $179 \mathrm{~cm}$, body mass index: 31.7 ) with large gallstone was scheduled to undergo elective laparoscopic cholecystectomy. He had a history of gout, gastroesophageal reflux disease, and moderate obesity. He was considered as ASA-2 according to the American Society of Anesthesiologists. He consented for ESP block in case of OC.

Anesthesia induction was performed using fentanyl 100 $\mu \mathrm{g}$, propofol $2 \mathrm{mg} / \mathrm{kg}$, and rocuronium bromide $50 \mathrm{mg}$ intravenous (iv). Following intubation, anesthesia was maintained with I.0 MAC of sevoflurane in air-oxygen mixture with $\mathrm{FiO}_{2} 0.4$. Perioperative bolus of lidocaine $1.5 \mathrm{mg} / \mathrm{kg}$ followed by infusion of lidocaine $1.5 \mathrm{mg} / \mathrm{kg} / \mathrm{h}$ and bolus of ketamine $30 \mathrm{mg}$, paracetamol $\mathrm{l} \mathrm{g}$, and morphine $20 \mathrm{mg}$ was given iv. After $3.5 \mathrm{~h}$, it was decided to change surgical procedure due to technical difficulties to OC (Fig. I). 


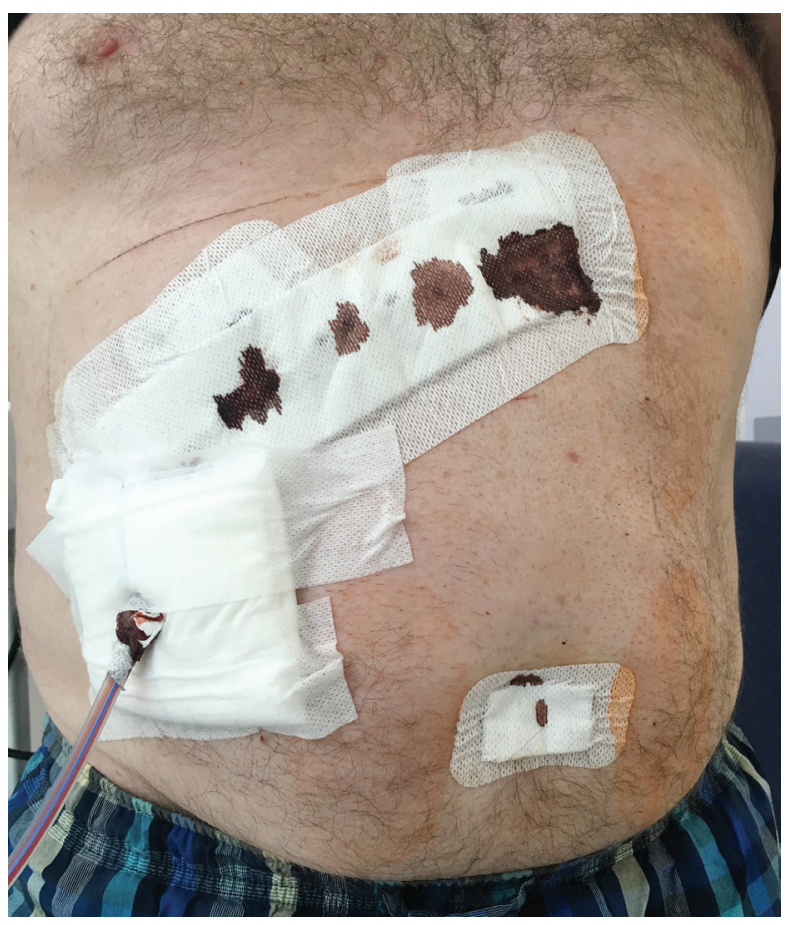

Figure 1. Surgical wound after open cholecystectomy.

Total surgical time was $320 \mathrm{~min}$, and time under anesthesia was $400 \mathrm{~min}$.

\section{ESP block}

At the end of surgery, the patient was placed on the left lateral decubitus position, and right-sided ultrasoundguided ESP block was performed under full aseptic conditions using high frequency linear probe (Sonosite EDGE-2, HFL Probe 6-13 MHz) using standard epidural kit (I6 G Tuohy needle and $18 \mathrm{G}$ epidural catheter; Smiths Medical). ESP was located at the T6 level, and after opening the space between the transverse process of T6 and erector spinae muscle using $5 \mathrm{~mL}$ of normal saline, the catheter was inserted from cranial to caudal direction, so the tip of the catheter was on top of the T7 transverse process. Further, bolus $20 \mathrm{~mL}$ of local anesthesia $(0.5 \%$ levobupivacaine) was injected through the catheter under direct ultrasound control, and spread deep to erector spinae muscle was observed. Bacterial filter was attached. The catheter was then secured with tissue glue (Dermabond), covered by clear dressing (Tegaderm), and taped over his shoulder to the right chest (Fig. 2).

After extubation in the operating theatre, the patient was transferred to the recovery room. Patient's numerical rating scale (NRS) was $1 / 10$ at rest and when coughing. Morphine patient-controlled analgesia (PCA) pump was attached as rescue analgesia for the first $24 \mathrm{~h}$. The patient was observed in the recovery room overnight and discharged to the surgical ward $24 \mathrm{~h}$ after surgery. During the first $24 \mathrm{~h}$, he used $5 \mathrm{mg}$ of morphine through his PCA pump mainly for buttock pain due to his prolonged stay in the bed and chair. Local anesthesia boluses $(20 \mathrm{~mL}$ $0.25 \%$ levobupivacaine) were administered in 12-hour in-

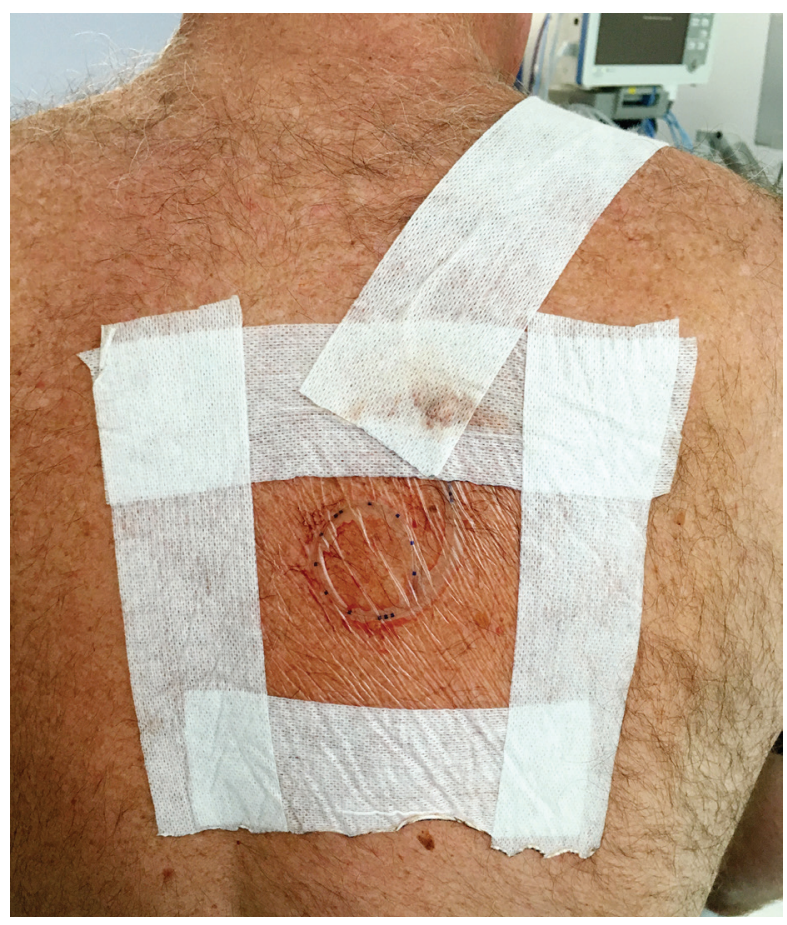

Figure 2. Erector spinae catheter secured on right shoulder.

tervals for up to 4 days. The patient was prescribed short release oxycodone (Shortec) 5-10 mg on demand (maximum 4 hourly). After $96 \mathrm{~h}$, the ESP catheter was removed. His NRS during his entire stay in the hospital was $<3 / 10$, and he has not used any oxycodone. The patient was discharged home with regular paracetamol I $\mathrm{g}$ four times a day (QDS) and, as required, codeine $30 \mathrm{mg}$ QDS orally for further 3-5 days.

\section{DISCUSSION}

ESP was first described for the successful treatment of thoracic neuropathic pain. ${ }^{[I]}$ Various other studies showed that ESP was an effective analgesic method in bariatric surgery, pneumothorax, and major abdominal surgery when performed at upper/mid thoracic vertebral levels (T4-T8). ${ }^{[2-6]}$ The LA injected in ESP spreads in the paravertebral space, allowing the effective analgesia for somatic and visceral pain. ${ }^{[3]}$ Bilateral ESP block has been found to have a similar effect as epidural analgesia for major abdominal surgery. ${ }^{[3,4]}$

Injection of $20 \mathrm{~mL}$ of fluid at the T7 level to ESP in cadavers spreads toward C7/T2 cranially and L2/3 caudally according to one cadaveric study. ${ }^{[7]}$ ESP block can be performed at the T4-T5 level for breast and thoracic surgeries and T7-T8 levels for abdominal surgeries. ${ }^{[2,5,7]}$

We report our case in which ESP block was successfully performed in a patient undergoing unexpected OC. Pain after $\mathrm{OC}$ has somatic and visceral origin. Visceral pain is due to the trauma of gallbladder resection, and somatic pain is due to the subcostal large skin incision. Other effective analgesic methods have been described for use after OC. Oblique subcostal transversus abdominis plane 
(TAP) block is one of these techniques; however, it only covers somatic pain from the anterolateral abdominal wall. ${ }^{[8]}$ We selected ESP block due to its effect on visceral nerve fibers. We demonstrated that ESP block offers effective analgesia after OC. Morphine PCA represents a standard for analgesia during the first $24 \mathrm{~h}$ after $O C$. Regular paracetamol and oral opioids (oxycodone or oral morphine) are routinely used as standard analgesia in our institution. Even though the ESP block is a relatively new regional technique, it has many advantages among other regional techniques for thoracic and abdominal procedures, such as thoracic epidural, paravertebral, and other fascial plane blocks (pectoralis nerve, serratus plane, and various TAP block techniques). Recently published case series of continuous ESP showed good analgesia for similar open surgical procedures requiring incision in the right subcostal space; however, their indication was liver resection in one case and nephrectomy in another patient. [9] One case report described the use of continuous ESP block via catheter in a septic intensive care unit patient undergoing emergency $\mathrm{OC}$. In this case, continuous infusion of $0.2 \%$ ropivacaine $4-6 \mathrm{ml} / \mathrm{h}$ was used. ${ }^{[10]}$ Our case report suggests that the continuous ESP block using intermittent boluses can be successfully used for postoperative analgesia as a part of multimodal analgesia regimen even in procedures such as $\mathrm{OC}$, which are associated with highintensity postoperative pain.

In conclusion, this case report has demonstrated that ESP block can be successfully used in upper abdominal surgical procedures including the right upper quadrant. To our knowledge, ESP block using intermittent boluses has not been reported previously for OC. ESP block is an effective and easy technique. It does not require a long time to perform in trained hands. More prospective, randomized studies are needed to determine the effectiveness and indications of ESP block for various surgical abdominal procedures when compared with other regional anesthesia techniques.

Informed Consent

Written informed consent was obtained from the patient for the publication of the case report and the accompanying images.

Peer-review

Internally peer-reviewed.

Conflict of Interest

None declared.

\section{REFERENCES}

1. Forero M, Adhikary SD, Lopez H, Tsui C, Chin KJ. The Erector Spinae Plane Block: A Novel Analgesic Technique in Thoracic Neuropathic Pain. Reg Anesth Pain Med 2016;41:621-7. [CrossRef]

2. Bonvicini D, Tagliapietra L, Giacomazzi A, Pizzirani E. Bilateral ultrasound-guided erector spinae plane blocks in breast cancer and reconstruction surgery. J Clin Anesth 2018;44:3-4. [CrossRef]

3. Chin KJ, Malhas L, Perlas A. The Erector Spinae Plane Block Provides Visceral Abdominal Analgesia in Bariatric Surgery: A Report of 3 Cases. Reg Anesth Pain Med 2017;42:372-6. [CrossRef]

4. Restrepo-Garces CE, Chin KJ, Suarez P, Diaz A. Bilateral Continuous Erector Spinae Plane Block Contributes to Effective Postoperative Analgesia After Major Open Abdominal Surgery: A Case Report. A A Case Rep 2017;9:319-21. [CrossRef]

5. Tulgar S, Selvi O, Kapakli MS. Erector Spinae Plane Block for Different Laparoscopic Abdominal Surgeries: Case Series. Case Rep Anesthesiol 2018;2018:3947281. [CrossRef]

6. Ueshima H, Otake H. Erector spinae plane block provides effective pain management during pneumothorax surgery. J Clin Anesth 2017;40:74. [CrossRef]

7. Chin KJ, Adhikary S, Sarwani N, Forero M. The analgesic efficacy of pre-operative bilateral erector spinae plane (ESP) blocks in patients having ventral hernia repair. Anaesthesia 2017;72:452-60. [CrossRef]

8. Shin HJ, Oh AY, Baik JS, Kim JH, Han SH, Hwang JW. Ultrasoundguided oblique subcostal transversus abdominis plane block for analgesia after laparoscopic cholecystectomy: a randomized, controlled, observer-blinded study. Minerva Anestesiol 2014;80:185-93.

9. Niraj G, Zubair T. Continuous Erector Spinae Plane (ESP) Analgesia In Different Open Abdominal Surgical Procedures: A Case Series. J Anesth Surg 2018;5:57-60. [CrossRef]

10. Kadam VR, Wahba M. Use of erector spinae plane block in open abdominal surgery and cancer pain. J Anaesthesiol Clin Pharmacol 2018;34:564-7.

\section{Açık Kolesistektomi Cerrahisinde Analjezi İçin Aralıklı Olarak Bolus Dozda Erektör Spina Plan Bloğu: Bir Olgu Sunumu}

Son zamanlarda çoğu laparoskopik olmak üzere çeşitli göğüs ve karın cerrahisi sonrası analjezi için ultrason kılavuzluğunda bolus dozla erektör spina plan bloğu (ESP) tanımlanmıştır. Bazı yazarlar ESP bloğunun hem viseral hem de somatik ağrıda etkisi olduğunu düşündürmektedir. Biz açık kolesistektomi (AK) cerrahisinde kateter yoluyla aralıklarla verilen bolus dozlarla sürekli ESP bloğunun başarıı uygulamasını tanımlamaktayız. Hastamıza laparoskopik kolesistektomi planlanmışken beklenmedik şekilde açık kolesistektomiye geçilmiştir. Sürekli ESP bloğu cerrahi sonrası 98 saat boyunca iyi bir analjezi sağlamıştır. Bilgilerimize göre AC için aralıklı bolus dozlarla sağlanan sürekli ESP bloğuna ilişkin ilk olgu raporudur.

Anahtar Sözcükler: Açık kolesistektomi; erktör spinaplan bloğu aralıklı boluslar; kateter; laparotomi. 